\title{
Effect of immobilized cells in calcium alginate beads in alcoholic fermentation
}

\author{
Juliana C Duarte ${ }^{1,2}$, J Augusto R Rodrigues ${ }^{1 *}$, Paulo J S Moran', Gustavo P Valença² and José R Nunhez ${ }^{2}$
}

\begin{abstract}
Saccharomyces cerevisiae cells were immobilized in calcium alginate and chitosan-covered calcium alginate beads and studied in the fermentation of glucose and sucrose for ethanol production. The batch fermentations were carried out in an orbital shaker and assessed by monitoring the concentration of substrate and product with HPLC. Cell immobilization in calcium alginate beads and chitosan-covered calcium alginate beads allowed reuse of the beads in eight sequential fermentation cycles of $10 \mathrm{~h}$ each. The final concentration of ethanol using free cells was $40 \mathrm{~g} \mathrm{~L}^{-1}$ and the yields using glucose and sucrose as carbon sources were $78 \%$ and $74.3 \%$, respectively. For immobilized cells in calcium alginate beads, the final ethanol concentration from glucose was $32.9 \pm 1.7 \mathrm{~g} \mathrm{~L}^{-1}$ with a $64.5 \pm 3.4 \%$ yield, while the final ethanol concentration from sucrose was $33.5 \pm 4.6 \mathrm{~g} \mathrm{~L}^{-1}$ with a $64.5 \pm 8.6 \%$ yield. For immobilized cells in chitosan-covered calcium alginate beads, the ethanol concentration from glucose was $30.7 \pm 1.4 \mathrm{~g} \mathrm{~L}^{-1}$ with a $61.1 \pm 2.8 \%$ yield, while the final ethanol concentration from sucrose was $31.8 \pm 6.9 \mathrm{~g} \mathrm{~L}^{-1}$ with a $62.1 \pm 12.8 \%$ yield. The immobilized cells allowed eight $10 \mathrm{~h}$ sequential reuse cycles to be carried out with stable final ethanol concentrations. In addition, there was no need to use antibiotics and no contamination was observed. After the eighth cycle, there was a significant rupture of the beads making them inappropriate for reuse.
\end{abstract}

Keywords: Immobilized cells, Fermentation, Ethanol, Glucose, Sucrose, Alginate

\section{Introduction}

Due to the gradual depletion of crude oil and environmental problems caused as a result of the growing consumption of oil and its derivatives, biomass and bioenergy have recently been attracting more attention. Therefore, it is important to study and develop alternatives that are both renewable and environmentally friendly. Ethanol has been considered an alternative to oil, since it is more environmentally friendly and is a renewable energy source (Bai et al. 2008; Lin and Tanaka 2006; Liu et al. 2009; Najafpour et al. 2004; Rattananpan et al. 2011; Xu et al. 2005). In Brazil ethanol is produced from sugar cane (Andrade 2007; Borges 2008; Pacheco 2010; Wendhausen et al. 2001) and the country is the largest exporter and second largest producer of ethanol, second only to the U.S., where it is produced primarily from corn (Borges 2008; Pacheco 2010). In addition, Brazil has favorable soil and climatic conditions and is recognized as a technology leader in ethanol production from sugar cane with the world's greatest potential for

\footnotetext{
* Correspondence: jaugusto@iqm.unicamp.br

'Institute of Chemistry, University of Campinas, Campinas, SP 13083-970, Brazil Full list of author information is available at the end of the article
}

increasing its production of biofuels (Borges 2008; Pacheco 2010; Rodrigues 2011). In Brazil the development of technologies that can improve the performance of ethanol production has gained considerable importance over the past 35 years. In this scenario, cell immobilization has been used for ethanol production in bioreactors in order to decrease the inhibition caused by high concentrations of substrate and product, thus increasing ethanol production and reducing its costs. There are several studies reporting the use of immobilized cells in various supports for a more economical production of ethanol. These systems are attractive and promising, since production is higher than that observed for free cells (Bai et al. 2008; Lin and Tanaka 2006; Najafpour et al. 2004; Inloes et al. 1983; Puligundla et al. 2011; Yao et al. 2011; Ylitervo et al. 2011; Yu et al. 2010). Each immobilization method has its advantages and disadvantages. The procedure of immobilization in alginate beads is not only inexpensive but also easy to carry out and provides extremely mild conditions, so there is a higher potential for industrial application (Zhou et al. 2010). Calcium alginate beads are one of the most commonly used supports for the immobilization of cells. They offer several 
Table 1 Ethanol concentration, yield and cell growth in aqueous medium after glucose fermentation by free cells and immobilized cells of Saccharomyces cerevisiae

\begin{tabular}{cccc}
\hline & Free cells & Immobilized cells CAB $^{\mathbf{a}}$ & Immobilized cells CCCAB $^{\mathbf{b}}$ \\
\hline Ethanol concentration $\left(\mathbf{g ~ L}^{-1}\right)$ & 40 & $32.9 \pm 1.7^{*}$ & $30.7 \pm 1.4^{*}$ \\
Yield (\%) & 78 & $64.5 \pm 3.4^{*}$ & $61.1 \pm 2.8^{*}$ \\
Cell growth in aqueous medium $\left(\mathbf{g ~ L}^{-1}\right)$ & 17.6 & $0.19 \pm 0.12^{*}$ & $0.09 \pm 0.05^{*}$ \\
\hline
\end{tabular}

${ }^{a}$ CAB: calcium alginate beads.

${ }^{b}$ CCCAB: chitosan-covered calcium alginate beads.

${ }^{*}$ Average data for eight successive fermentation cycles.

advantages as a support, such as good biocompatibility, low cost, easy availability, and ease of preparation. However, there are some disadvantages associated with their use, such as gel degradation, severe mass transfer limitations, low mechanical strength (causing cells to be released from the support), and large pore size (Zhou et al. 2010; Bangrak et al. 2011). In order to optimize encapsulation efficiency and avoid the release of cells from the support, various methods have been proposed (Roca et al. 1996; Winkelhausen et al. 2010), including covalent cross-linking with polymers such as chitosan and glutaraldehyde (Zhou et al. 2010).

Immobilized cells have some advantages over free cells, such as higher cell density per volume of reactor, easier separation from the reaction medium, continuous operation without cells being carried away downstream, reduction of the adaptation phase (lag phase), a higher substrate conversion, less inhibition by products, reduced reaction time, and control of cell replication (biomass growth) (Wendhausen 1998).

This work studies the immobilization of cells of the JAY 270 strain of the yeast Saccharomyces cerevisiae, using calcium alginate and chitosan-covered calcium alginate beads. Glucose and sucrose are used as carbon sources for the fermentation. Chitosan, a linear polysaccharide composed of randomly $\beta$-(1-4)-linked-Dglucosamine (deacetylated unit) and N-acetyl-D-glucosamine (acetylated unit) (Canella and Garcia 2001), was used as the external layer of the calcium alginate beads. Alginate and chitosan, which are polysaccharide biopolymers, have been the focal point of an expanding number of studies that address their potential for use in enzyme/ cell encapsulation (Zhou et al. 2010). When calcium alginate is mixed with chitosan, a strong ionic interaction occurs between the amino groups of chitosan and carboxyl groups of alginate for the formation of a polyelectrolyte complex (PEC), which results in better mechanical properties of the support (Ngah and Fatinathan 2008; Rodrigues 2008; Shu and Zhu 2002; Xu et al. 2007).

\section{Materials and methods}

Materials

\section{Microorganism}

The JAY 270 strain of Saccharomyces cerevisiae was obtained from the Institute of Biology at UNICAMP. This strain had been studied in previous experiments (Argueso et al. 2009) and showed a good ethanol production and high biomass production.

\section{Chemicals}

Glucose and acetic acid were obtained from Synth; sucrose, from Aldrich; yeast extract, from Oxoid; peptone and malt extract, from Himedia, sodium alginate (average viscosity) and chitosan (medium molecular weight, degree of deacetylation 75-85\%), from Sigma-Aldrich; and calcium chloride, from Aldrich Chemical Company, Inc.

\section{Methods}

\section{Growing medium}

The yeast cells were grown in a sterile solution $\left(121^{\circ} \mathrm{C}\right.$, $15 \mathrm{~min}$.) containing $10 \mathrm{~g} \mathrm{~L}^{-1}$ glucose, $5 \mathrm{~g} \mathrm{~L}^{-1}$ peptone, $3 \mathrm{~g} \mathrm{~L}^{-1}$ yeast extract, and $3 \mathrm{~g} \mathrm{~L}^{-1}$ malt extract. After one day, the mixture was centrifuged (2000 rpm, $20 \mathrm{~min}$.) and suspended in sterile water $(0.10 \mathrm{~L})$.

\section{Fermentation medium with glucose}

A sterile solution $\left(121^{\circ} \mathrm{C}, 20 \mathrm{~min}\right.$.) was prepared with $100 \mathrm{~g} \mathrm{~L}^{-1}$ glucose, $20 \mathrm{~g} \mathrm{~L}^{-1}$ peptone, and $10 \mathrm{~g} \mathrm{~L}^{-1}$ yeast

Table 2 Ethanol concentration, yield and cell growth in aqueous medium after sucrose fermentation by free cells and immobilized cells of Saccharomyces cerevisiae

\begin{tabular}{cccc}
\hline & Free cells & Immobilized cells $\mathbf{C A B}^{\mathbf{a}}$ & Immobilized cells CCCAB $^{\mathbf{b}}$ \\
\hline Ethanol concentration $\left(\mathbf{g ~ ~ L ^ { - 1 }}\right)$ & 40 & $33.5 \pm 4.6^{*}$ & $31.8 \pm 6.9^{*}$ \\
Yield (\%) & 74.3 & $64.5 \pm 8.6^{*}$ & $62.1 \pm 12.8^{*}$ \\
Cell growth in aqueous medium $\left(\mathbf{g ~ L}^{-1}\right)$ & 15.6 & $0.40 \pm 0.38^{*}$ & $0.26 \pm 0.30^{*}$ \\
\hline
\end{tabular}

\footnotetext{
a CAB: calcium alginate beads.

b CCCAB: chitosan-covered calcium alginate beads.

* Average data for eight successive fermentation cycles.
} 


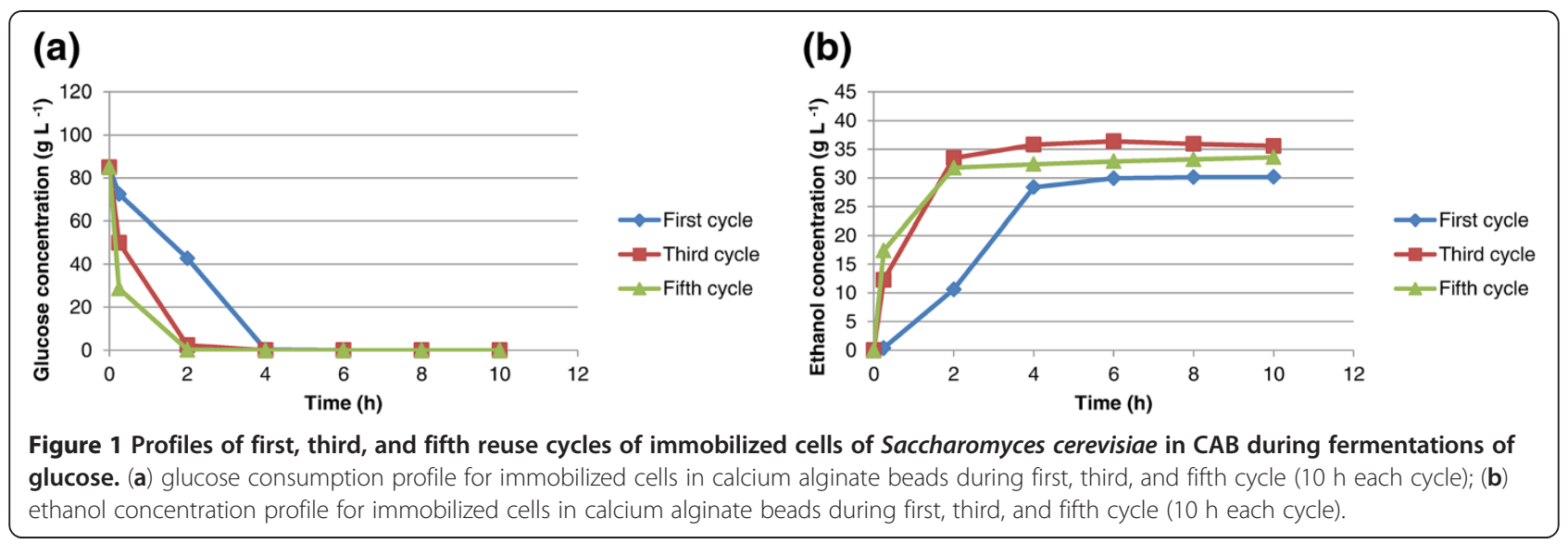

extract. This solution was used in the batch fermentation experiments.

\section{Fermentation medium with sucrose}

A sterile solution $\left(121^{\circ} \mathrm{C}, 20 \mathrm{~min}\right.$.) was prepared with $100 \mathrm{~g} \mathrm{~L}^{-1}$ sucrose, $20 \mathrm{~g} \mathrm{~L}^{-1}$ peptone, and $10 \mathrm{~g} \mathrm{~L}^{-1}$ yeast extract. This solution was also used in the batch fermentation experiments.

\section{Calcium alginate beads}

For the immobilization in beads, 3\% (w/v) sodium alginate was dissolved in $0.10 \mathrm{~L}$ water and added to a $0.10 \mathrm{~L}$ suspension of $S$. cerevisiae in a beaker. The solution was mildly shaken. $\mathrm{A} \mathrm{CaCl}_{2}$ solution with a final concentration of $2 \%(\mathrm{w} / \mathrm{v})$ was prepared in a separate beaker. The mixture containing the cells and the sodium alginate was added dropwise to $0.150 \mathrm{~L}$ of the $\mathrm{CaCl}_{2}$ solution using a $0.010 \mathrm{~L}$ syringe. The beads were hardened in this solution for $1 \mathrm{~h}$. After hardening in the $\mathrm{CaCl}_{2}$ solution, the beads were rinsed with sterile water to be used thereafter in the fermentation experiments. The beads were got with a diameter approximately between 3 to $4 \mathrm{~mm}$.

\section{Chitosan-covered calcium alginate beads}

For the immobilization in beads, $3 \%(\mathrm{w} / \mathrm{v})$ sodium alginate was dissolved in $0.10 \mathrm{~L}$ water and added to a $0.10 \mathrm{~L}$ suspension of $S$. cerevisiae in a beaker. The solution was mildly shaken. $\mathrm{A} \mathrm{CaCl}_{2}$ solution with a final concentration of $2 \%(\mathrm{w} / \mathrm{v})$ was prepared in a separate beaker. A solution of $0.25 \%(\mathrm{w} / \mathrm{v})$ chitosan in $5 \%$ acetic acid was prepared in another beaker. The mixture containing the cells and the sodium alginate was added dropwise to $0.150 \mathrm{~L}$ of the $\mathrm{CaCl}_{2}$ solution using a $0.010 \mathrm{~L}$ syringe. The beads were hardened in this solution for $1 \mathrm{~h}$. After hardening in the $\mathrm{CaCl}_{2}$ solution, the beads were rinsed with sterile water and then added to the $0.25 \%$ chitosan solution and kept under mild shaking for 30 minutes. The beads were then rinsed with sterile water to be used thereafter in the fermentation experiments. The beads were got with a diameter approximately between 3 to $4 \mathrm{~mm}$.

Batch fermentation experiments using the immobilized cells Approximately $100 \mathrm{~g}$ of calcium alginate beads was added to a $1.0 \mathrm{~L}$ Erlenmeyer flask containing $0.20 \mathrm{~L}$ of the fermentation medium with glucose or sucrose as carbon source. All steps prior to fermentation were carried
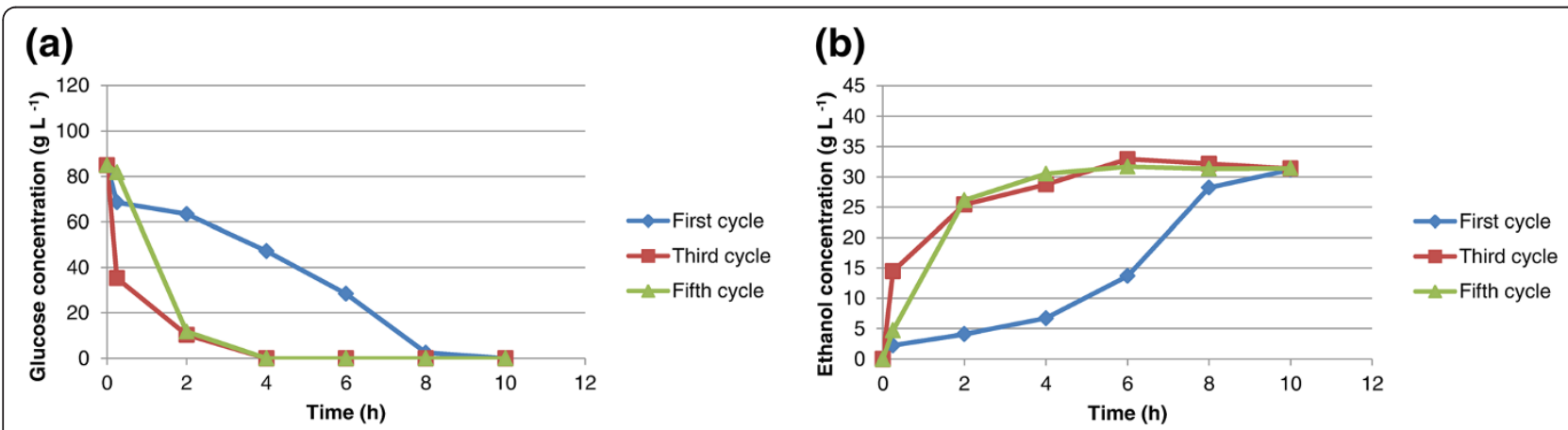

Figure 2 Profiles of first, third, and fifth reuse cycles of immobilized cells of Saccharomyces cerevisiae in CCCAB during fermentations of glucose. (a) glucose consumption profile for immobilized cells in chitosan-covered calcium alginate beads during first, third, and fifth cycle (10 h each cycle); (b) ethanol concentration profile for immobilized cells in chitosan-covered calcium alginate beads during first, third, and fifth cycle (10 h each cycle). 


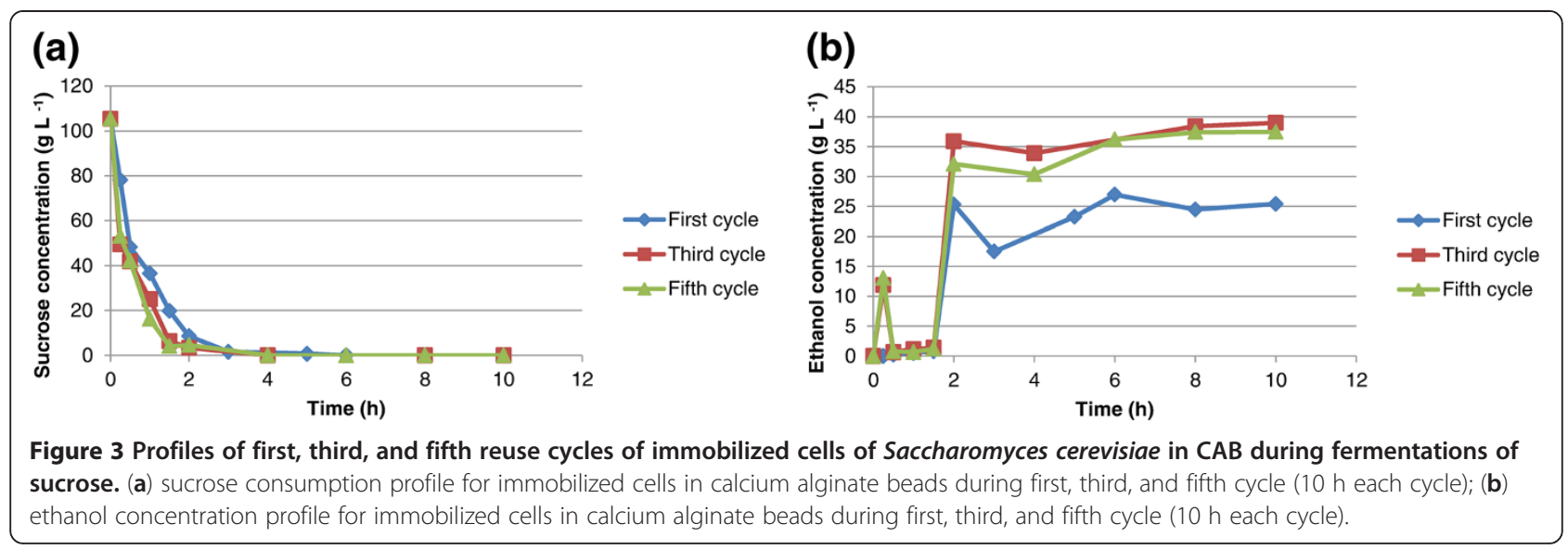

out under sterile conditions. The procedure described above was carried out for chitosan-covered calcium alginate beads. The four flasks were sealed with a cotton plug and placed in an orbital shaker for $10 \mathrm{~h}$ at $30^{\circ} \mathrm{C}$ and 200 rpm. Samples were collected during the fermentation period. After $10 \mathrm{~h}$, the beads were filtered and rinsed with sterile water and added to a fresh fermentation medium (with glucose or sucrose as carbon sources for calcium alginate and chitosan-covered calcium alginate beads) as described above. This procedure was repeated eight times for the successive fermentation cycles.

\section{Batch fermentation experiments using free cells}

In order to compare the performance of the immobilized cells, a parallel experiment using free cells for the fermentation was carried out using the same mass of cells as that used in the immobilized beads. The experiments were carried out under the same experimental conditions with either glucose or sucrose as carbon source.

\section{Analytical methods}

Ethanol, glucose, and sucrose concentrations were determined using high-performance liquid chromatography equipment (Agilent Technologies 1200 series) equipped with a Aminex ${ }^{\bullet} \mathrm{HPX}-87 \mathrm{H}$ column (Biorad) and refractive index detector (RID). Cell growth was determined by optical density at $600 \mathrm{~nm}$ in an Agilent HP 8453 spectrophotometer using the fermentation medium as blank.

\section{Results}

Eight sequential fermentation cycles using immobilized cells in calcium alginate and chitosan-covered calcium alginate beads were carried out with $100 \mathrm{~g} \mathrm{~L}^{-1}$ glucose or sucrose as carbon source. The cycles lasted $10 \mathrm{~h}$ each and every experiment used approximately $6 \mathrm{~g}$ of wet yeast cells. When mixed with the alginate, these cells had a final weight of $100 \mathrm{~g}$, so the immobilized cell concentration in the beads was approximately $60 \mathrm{~g} \mathrm{~L}^{-1}$. Ethanol yield and cell growth in aqueous medium are slightly different in fermentation systems for free cells from those for immobilized cells. The ethanol concentration, yield, and cell growth in aqueous medium for glucose or sucrose fermentation are shown in Tables 1 and 2, respectively. The yield is defined as the amount of ethanol produced in relation to the maximum ethanol that could be produced from the carbon source (glucose

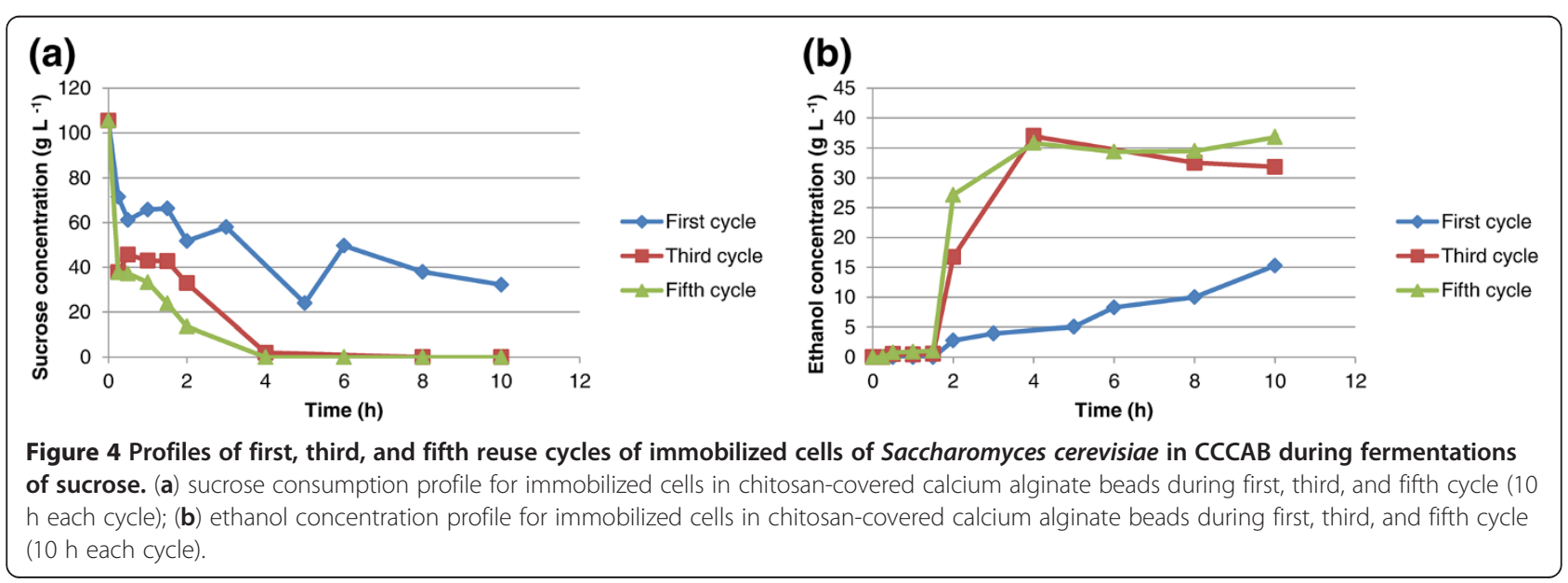




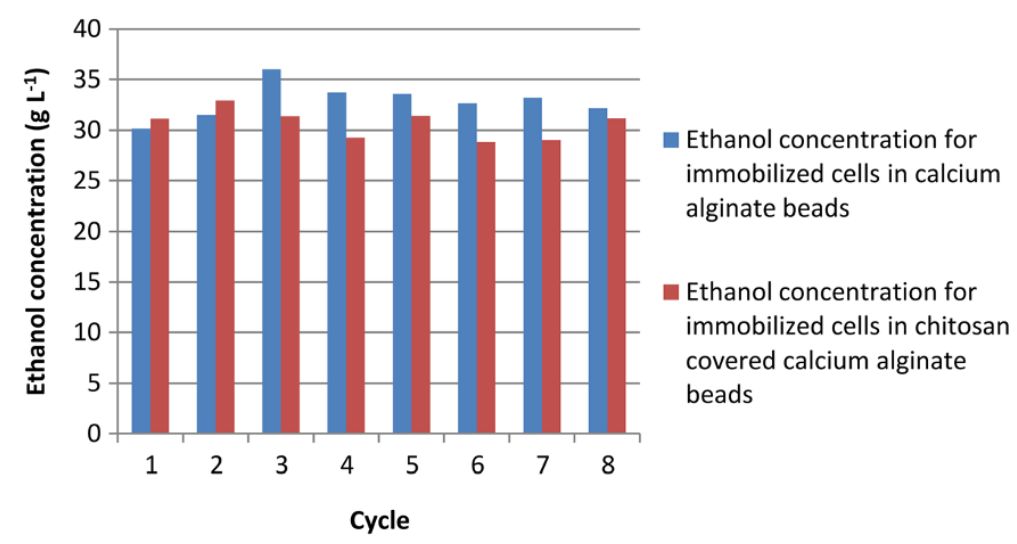

Figure 5 Final ethanol concentration at the end of each cycle using glucose as carbon source.

or sucrose). For example, for glucose, 1 mole of glucose could produce 2 moles of ethanol if the conversion were $100 \%$. For free cells, the yield is the value after one experiment; however, since immobilized cells were used in eight cycles, the yield is calculated as the average of the yields for all eight cycles. The same applies to cell growth in aqueous medium and ethanol concentration. As shown in Table 1, the yields from glucose for free cells, immobilized cells in calcium alginate beads, and immobilized cells in chitosan-covered calcium alginate beads are $78 \%, 64.5 \pm 3.4 \%$, and $61.1 \pm 2.8 \%$, respectively. As shown in Table 2, the yields from sucrose for free cells, immobilized cells in calcium alginate beads, and immobilized cells in chitosan-covered calcium alginate beads are $74.3 \%, 64.5 \pm 8.6 \%$, and $62.1 \pm 12.8 \%$, respectively. A low yield has been observed in fermentations with immobilized cells, which might be due to diffusional problems because entrapped cells may not have effective contact with essential nutrients in the broth or the cells may be inhibited by the product (Nikolic et al. 2010). In this article, cell growth in an aqueous medium is defined as the number of cells formed during fermentation. For the free cells, cell growth in aqueous medium is estimated as the total number of cells after the cycle less the cells introduced at the beginning of fermentation. For immobilized cells, cell growth in aqueous medium was estimated as the number of cells released from the beads. It is possible that some cell growth might have occurred inside the beads. However, since all beads were used for eight cycles, cell growth was not determined. The fermentations using calcium alginate and chitosan-covered calcium alginate beads with glucose as carbon source are shown in Figures 1 and 2, respectively. The curves are for the first, third, and fifth cycles. The maximum ethanol concentration was reached after $4 \mathrm{~h}$ of reaction for the immobilized cells in beads without chitosan and after $6 \mathrm{~h}$ for those immobilized in beads with chitosan. The fermentations using calcium alginate and chitosan-covered calcium alginate beads with sucrose as carbon source are shown in Figures 3 and 4, respectively. These figures contain the curves for the first, third, and fifth cycles. Unlike the fermentations using glucose, the maximum ethanol concentration was reached after $2 \mathrm{~h}$ of reaction for the immobilized cells without chitosan and after $4 \mathrm{~h}$ for those with chitosan. It can be observed in all the figures that the increase in

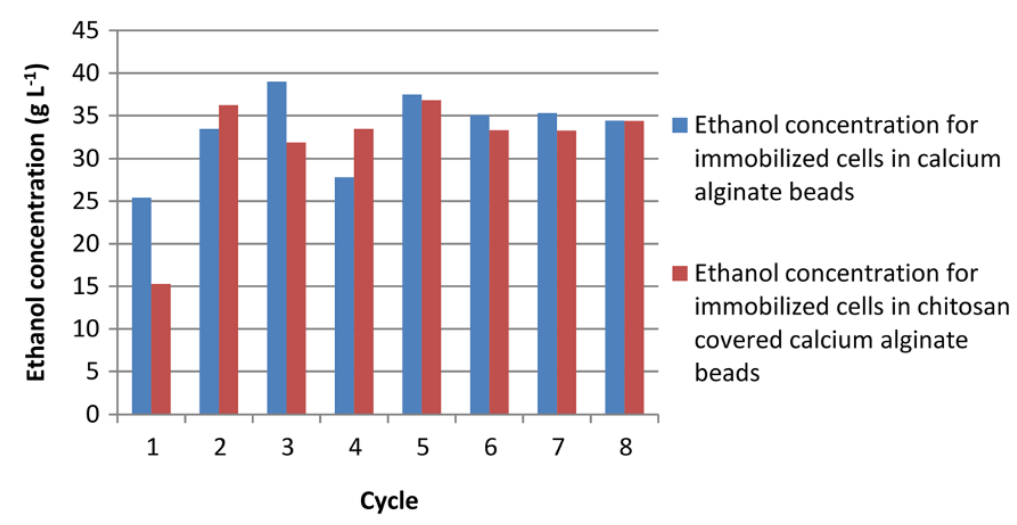

Figure 6 Final ethanol concentration at the end of each cycle using sucrose as carbon source. 


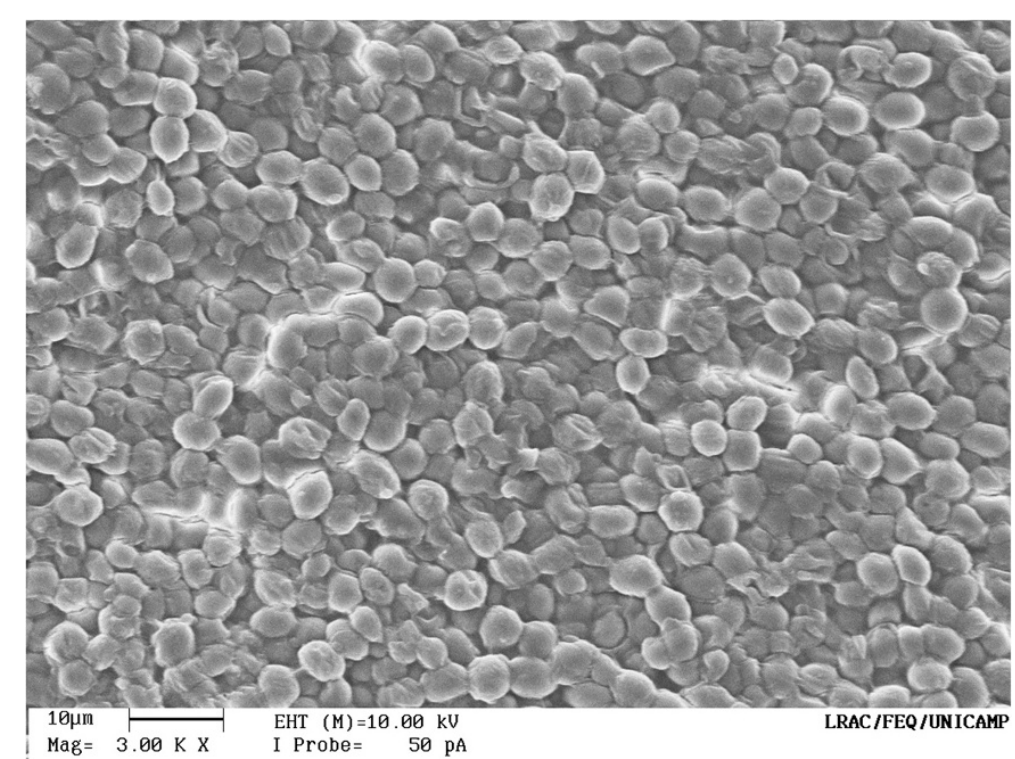

Figure 7 SEM image to the calcium alginate bead.

ethanol concentration and the decrease in sugar concentration in the first cycle are considerably lower than those observed in the third and fifth cycles. One possible explanation is that during the first cycle, cells are in an adaptation phase and they might be suffering stress caused by immobilization. In addition, cell growth within the beads should contribute to the increased final ethanol concentration in later cycles. The only data on ethanol concentration for the second, fourth, sixth, seventh, and eighth cycles is the concentration at the beginning and at the end of the experiment. The final ethanol concentrations at the end of each cycle are shown in
Figures 5 and 6 for glucose and sucrose, respectively. It can be observed that the final ethanol concentration was considerably constant after the first cycle in both figures when using immobilized cells in calcium alginate beads and in chitosan-covered calcium alginate beads.

\section{Discussion}

Cell immobilization in beads offers important advantages, such as ease of cell separation from the medium, a decrease in costs due to cell reuse in subsequent reaction cycles, and a reduced possibility of contamination. Furthermore, the results of cell immobilization showed a

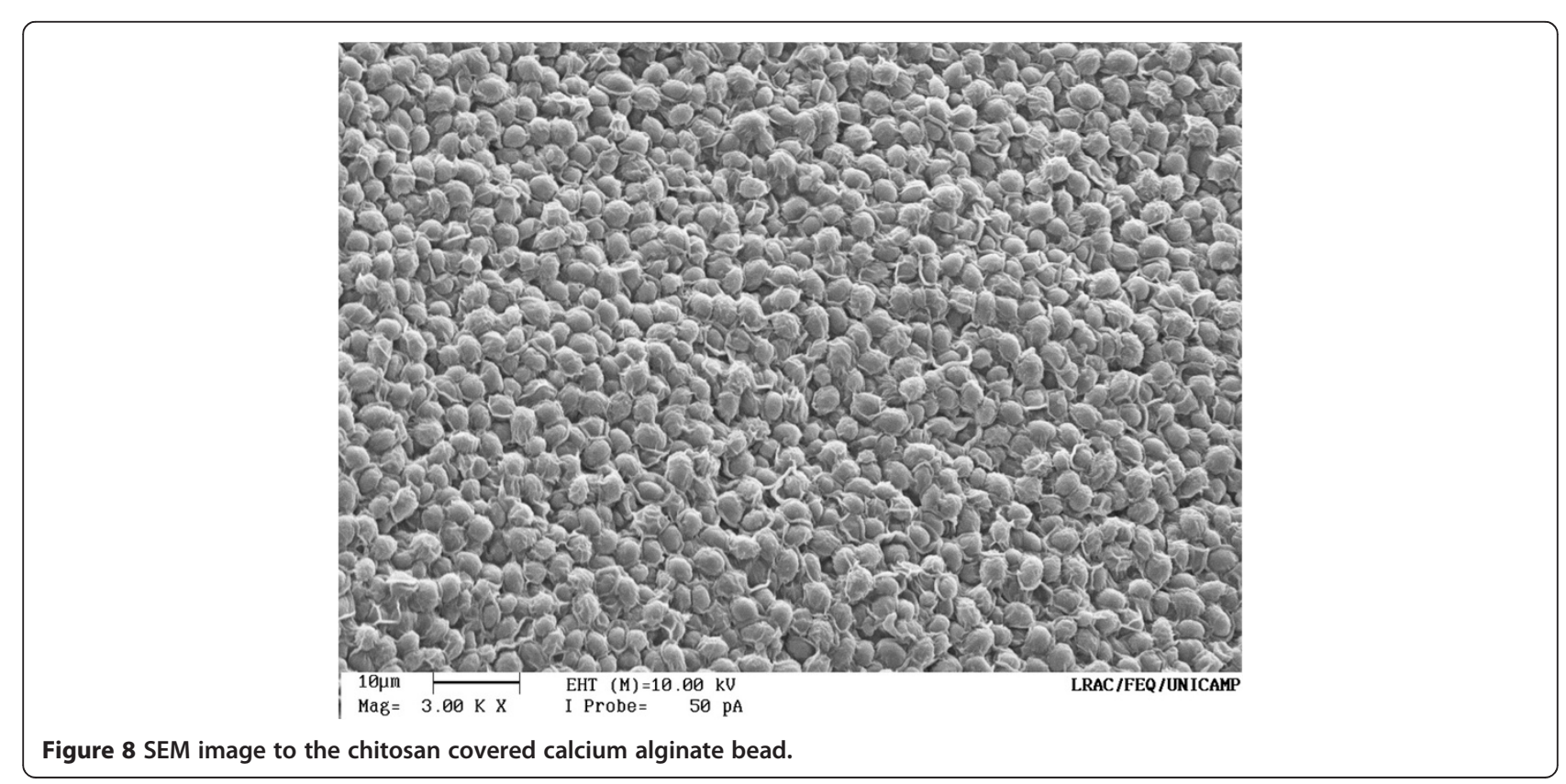


stable final ethanol concentration throughout the cycles (Figures 5 and 6) so these immobilized cells could be employed in a continuous process in a tubular reactor. There was no need to use antibiotics during fermentation and no contamination was observed throughout the experiment. Contamination is a serious technical and economic problem with the use of free cells in mills where cells must be recycled.

The final ethanol concentration and yield were higher for free cell fermentation systems using glucose or sucrose than for systems carried out with immobilized cells. Chitosan-covered calcium alginate beads were not mechanically more resistant than beads without chitosan. When using chitosan, cell growth in aqueous medium was slightly lower than that for the beads without it. This had been expected, since chitosan acts as a barrier to cell release. Figures 7 and 8 show the scanning electron microscope (SEM) images to the calcium alginate beads and to the chitosan-covered calcium alginate beads, respectively. It can be noticed in Figure 8, a sort of chitosan film cover the yeast cells, keeping them more adherent to the bead surface. These SEM images of the beads were acquired before to use them in fermentations. The final ethanol concentration using immobilized cells was similar, even after eight sequential fermentation cycles. For free cells, the final ethanol concentration was $40 \mathrm{~g} \mathrm{~L}^{-1}$, but this experiment was carried out without cell reuse. For immobilized cells, it was about $30 \mathrm{~g} \mathrm{~L}^{-1}$ in each cycle with cell reuse. Our results show an improvement over those observed by Ghorbani et al. (2011), who showed a final ethanol concentration of $19.15 \mathrm{~g} \mathrm{~L}^{-1}$ using sodium-alginate immobilized yeast in an immobilized cell reactor (ICR) with a feed containing $150 \mathrm{~g} \mathrm{~L}^{-1}$ of molasses. Using a $10 \%$ initial glucose concentration Birol et al. (1998) observed a final ethanol concentration of $41 \mathrm{~g} \mathrm{~L}^{-1}$, which was similar to the one we obtained for free cell fermentation. Our results for immobilized cells are also similar to those reported by Shafaghat et al. (2011), where continuous ethanol fermentation in ICR using molasses and immobilized cells in calcium alginate achieved a maximum ethanol concentration of $45.5 \mathrm{~g} \mathrm{~L}^{-1}$ in an experiment with an initial sugar concentration of $100 \mathrm{~g} \mathrm{~L}^{-1}$. It was observed (Eiadpum et al. 2012) that a co-culture of Kluyveromyces marxianus and Saccharomyces cerevisiae immobilized on thin-shell silk cocoon was effective for ethanol fermentation at a high-temperature, generating ethanol concentrations of 81.4 and $77.3 \mathrm{~g} \mathrm{~L}^{-1}$ when using temperatures of 37 and $40^{\circ} \mathrm{C}$ and an initial sugar concentration of $220 \mathrm{~g} \mathrm{~L}^{-1}$. Our results show that ethanol conversion time was longer on chitosan-covered calcium alginate beads than on calcium alginate beads. It was noticed that the chitosan-covered calcium alginate beads were slightly more robust than the calcium alginate beads after eight sequential fermentation cycles. However, this difference was not significant. Final ethanol concentration is due mostly to the immobilized cells since the cell concentration in aqueous medium due to the release from beads is negligible when compared to the cell concentration in the beads. It was possible to perform eight sequential cycles of $10 \mathrm{~h}$ each using immobilized cells. Since the maximum ethanol concentration was reached in $6 \mathrm{~h}$ for the chitosan-covered beads, it may be possible to increase significantly the number of cycles if the cycle time is reduced to $6 \mathrm{~h}$.

In conclusion, with immobilized cells it was possible to carry out eight sequential reuse cycles, generating a stable final ethanol concentration in each cycle. Therefore, this study suggests that the beads' robustness allows potential application in a continuous process in a tubular reactor. In addition, there was no need to use antibiotics and contamination was not observed. In comparing calcium alginate beads and chitosan-covered calcium alginate beads, it was observed that the chitosan cover did not improve the beads' robustness and, moreover, substrate consumption and ethanol production were slower because chitosan acted as a barrier to substrates and products.

\section{Competing interests}

The authors declare that they have no competing interests.

\section{Acknowledgments}

This research was supported by Conselho Nacional de Desenvolvimento Científico e Tecnológico - CNPq, Coordenação de Aperfeiçoamento de Pessoal de Nível Superior - CAPES, and Fundação de Amparo à Pesquisa do Estado de São Paulo - FAPESP.

\section{Author details}

${ }^{1}$ Institute of Chemistry, University of Campinas, Campinas, SP 13083-970, Brazil. ${ }^{2}$ School of Chemical Engineering, University of Campinas, Campinas SP 13083-852, Brazil.

Received: 6 March 2013 Accepted: 2 May 2013

Published: 30 May 2013

\section{References}

Andrade RR (2007) Procedimento para o desenvolvimento de um modelo matemático robusto para o processo de fermentação alcoólica, Dissertation. University of Campinas - UNICAMP, Brazil

Argueso JL, Carazzolle MF, Mieczkowski PA, Duarte FM, Netto OVC, Missawa SK, Galzerani F, Costa GGL, Vidal RO, Noronha MF et al (2009) Genome structure of a Saccharomyces cerevisiae strain widely used in bioethanol production. Genome Res 19:2258-2270

Bai FW, Anderson WA, Moo-Young M (2008) Ethanol fermentation technologies from sugar and starch feedstocks. Biotechnol Adv 26:89-105

Bangrak P, Limtong S, Phisalaphong M (2011) Continuous ethanol production using immobilized yeast cells entrapped in loofa-reinforced alginate carriers. Braz J Microbiol 42:676-684

Birol G, Doruker P, Kirdar B, Önsan Zl, Ülgen K (1998) Mathematical description of ethanol fermentation by immobilized Saccharomyces cerevisiae. Process Biochem 33:763-771

Borges PCS (2008) Otimização dinâmica da fermentação alcoólica no processo em batelada alimentada, Dissertation. Universidade Federal de Uberlândia, Brazil

Canella KMNC, Garcia RB (2001) Caracterização de quitosana por cromatografia de permeação em gel - influência do método de preparação e do solvente. Quim Nova 24:13-17 
Eiadpum A, Limtong S, Phisalaphong M (2012) High-temperature ethanol fermentation by immobilized co culture of Kluyveromyces marxianus and Saccharomyces cerevisiae. J Biosci Bioeng 114:325-329

Ghorbani F, Younesi H, Sari AE, Najafpour G (2011) Cane molasses fermentation for continuous ethanol production in an immobilized cells reactor by Saccharomyces cerevisiae. Renew Energ 36:503-509

Inloes DS, Taylor DP, Cohen SN, Michaels AS, Robertson CR (1983) Ethanol production by S. cerevisiae immobilized in hollow-fiber membrane bioreactors. Appl Environ Microb 46:264-278

Lin Y, Tanaka S (2006) Ethanol fermentation from biomass resources: Current state and prospects. Appl Microbiol Biot 69:627-642

Liu C, Wang F, Ou-Yang F (2009) Ethanol fermentation in a magnetically fluidized bed reactor with immobilized Saccharomyces cerevisiae in magnetic particles. Bioresource Technol 100:878-882

Najafpour G, Younesi H, Ismail KSK (2004) Ethanol fermentation in an immobilized cell reactor using Saccharomyces cerevisiae. Bioresource Technol 92:251-260

Ngah WSW, Fatinathan S (2008) Adsorption of Cu(II) ions in aqueous solution using chitosan beads, chitosan-GLA beads and chitosan-alginate beads. Chem Eng J 143:62-72

Nikolic S, Mojovic L, Pejin D, Rakin M, Vukasinovic M (2010) Production of bioethanol from corn meal hydrolizates by free and immobilized cells of Saccharomyces cerevisiae var. ellipsoideus. Biomass Bioenerg 34:1449-1456

Pacheco TF (2010) Fermentação alcoólica com leveduras de características floculantes em reator tipo torre com escoamento ascendente, Dissertation. Universidade Federal de Uberlândia, Brazil

Puligundla P, Poludasu RM, Rai JK, Obulan VSR (2011) Repeated batch ethanolic fermentation of very high gravity medium by immobilized Saccharomyces cerevisiae. Ann Microbiol 61:863-869

Rattananpan A, Limtong S, Phisalaphong M (2011) Ethanol production by repeated batch and continuous fermentations of blackstrap molasses using immobilized yeast cells on thin-shell silk cocoons. Appl Energ 88:4400-4404

Roca E, Meinander N, Núñez MJ, Hahn-Hägerdal B, Lema JM (1996) Continuous fermentation by conventional and recombinant Saccharomyces cerevisiae immobilized in Ca-alginate beads hardened with trivalent ion, In Progress in Biotechnology - Immobilized Cells - Basics and Applications, Proceedings of an International Symposium organized under auspices of The Working Party on Applied Biocatalysis of the European Federation of Biotechnology Noordwijkerhout: 26-29 November 1995. The Netherlands, pp 73-180

Rodrigues AP (2008) Preparação e caracterização de membranas de quitosana e alginato para aplicação na terapia de lesões, Dissertation. University of Campinas - UNICAMP, Brazil

Rodrigues JAR (2011) From the mill to a biorefinery. The sugar factory as an industrial enterprise for the generation of biochemicals and biofuels. Quim Nova 34:1242-1254

Shafaghat H, Najafpour GD, Rezaei PS, Sharifzadeh-Baei M (2011) Ethanol production with natural carbon sources in batch and continuous fermentation using free and immobilized Saccharomyces cerevisiae. J Sci Ind Res India 70:162-169

Shu XZ, Zhu KJ (2002) The release behavior of brilliant blue from calciumalginate gel beads coated by chitosan: The preparation method effect. Eur J Pharm Biopharm 53:193-201

Wendhausen R (1998) Estudo sobre utilização de crisotila como suporte de células de Saccharomyces cerevisiae para uso em processo contínuo de fermentação alcoólica e biorreduções, Dissertation. University of Campinas UNICAMP, Brazil

Wendhausen R, Fregonesi A, Moran PJS, Rodrigues JAR, Tonella E, Althoff K (2001) Continuous fermentation of sugar cane syrup using immobilized yeast cells. J Biosci Bioeng 91:48-52

Winkelhausen E, Velickova E, Amartey SA, Kuzmanova S (2010) Ethanol production using immobilized Saccharomyces cerevisiae in lyophilized cellulose gel. Appl Biochem Biotechnol 162:2214-2220

Xu TJ, Zhao XQ, Bai FW (2005) Continuous ethanol production using self-flocculating yeast in a cascade of fermentors. Enzyme Microb Tech 37:634-640

Xu Y, Zhan C, Fan L, Wang L, Zheng H (2007) Preparation of dual crosslinked alginate-chitosan blend gel beads and in vitro controlled release in oral sitespecific drug delivery system. Int J Pharm 336:329-337

Yao W, Wu X, Zhu J, Sun B, Zhang YY, Miller C (2011) Bacterial cellulose membrane - A new support carrier for yeast immobilization for ethanol fermentation. Process Biochem 46:2054-2058
Ylitervo P, Franzén CJ, Taherzadeh MJ (2011) Ethanol production at elevated temperatures using encapsulation of yeast. J Biotechnol 156:22-29

Yu J, Yue G, Zhong J, Zhang X, Tan T (2010) Immobilization of Saccharomyces cerevisiae to modified bagasse for ethanol production. Renew Energ 35:1130-1134

Zhou Z, Li G, Li Y (2010) Immobilization of Saccharomyces cerevisiae alcohol dehydrogenase on hybrid alginate-chitosan beads. Int J Biol Macromol 47:21-26

doi:10.1186/2191-0855-3-31

Cite this article as: Duarte et al:: Effect of immobilized cells in calcium alginate beads in alcoholic fermentation. AMB Express 2013 3:31.

\section{Submit your manuscript to a SpringerOpen ${ }^{\circ}$ journal and benefit from:}

- Convenient online submission

- Rigorous peer review

- Immediate publication on acceptance

- Open access: articles freely available online

- High visibility within the field

- Retaining the copyright to your article

Submit your next manuscript at $>$ springeropen.com 